$\mathbf{R}_{\text {ESEA }}^{\text {RCH }}$ RTCLe

Members of the Research Forum

Associate Author :

Southern Regional Station, ICAR

- National Dairy Research Institute, BENGALURU (KARNATAKA)

INDIA

AUTHOR FOR CORRESPONDENCE : S. PORCHEZHIYAN

Southern Regional Station, ICAR

- National Dairy Research Institute,

BENGALURU (KARNATAKA)

INDIA

Email:chezhivet@gmail.com

\section{Correlation effect of entrepreneurial behavioural components in dairying}

\author{
S. PORCHEZHIYAN, M. UMAMAGESWARI ${ }^{1}$ AND G. MANJUNATHA ${ }^{1}$
}

\begin{abstract}
The study was conducted in four northern districts of Tamil Nadu to assess the characteristics of entrepreneurial behaviour. A sample of 120 dairy farmers was selected randomly form selected blocks of the districts and the information was collected through structured interview schedule. The study revealed that entrepreneurial behaviour had positive and significant relationship with socio-personal variables viz., education, dairy farming experience and social participation, socio-economic variables viz., annual income, land holding, livestock possession and milk production and socio-psychological variables viz., extension participation, scientific orientation, attitude towards dairy farming and knowledge of farming enterprise. The extension agencies should aim at manipulating these variables to their advantage for promoting entrepreneurial behaviour among farmers and upliftment of socio-economic condition of the dairy farmers.
\end{abstract}

Key words : Dairying, Correlation between entrepreneurial behaviour

How to cite this paper : Porchezhiyan, S., Umamageswari, M. and Manjunatha, G. (2016). Correlation effect of entrepreneurial behavioural components in dairying. Vet. Sci. Res. J., 7(1) : 21-24.

Paper History : Received : 01.02.2016; Revised : 21.02.2016; Accepted : 12.03 .2016 